УДК 373.3/.5.016:5]:004

DOI: 10.37026/2520-6427-2020-103-3-55-61
Світлана ЛИТВИНОВА,

доктор педагогічних наук, старший науковий співробітник, в.о. заступника директора з наукової роботи Інституту інформаційних технологій $і$ засобів навчання НАПН Украӥни, м. Київ

\title{
ОРГАНІЗАЦІЯ ДИСТАНЦИЙНОЇ ФОРМИ НАВЧАННЯ В ЗАКЛАДАХ ЗАГАЛЬНОЇ СЕРЕДНЬОЇ ОСВІТИ У ПЕРІОД ПАНДЕМІЇ COVID-19
}

У статті схарактеризовано питання дистаниійного навчання учнів закладів загальної середньоі освіти (33СО) у період пандемії. Доведено, щзо, незважаючи на рекомендаиії ЮНЕСКО, дистаниійне навчання у вітчизняних закладах загальної середньої освіти реалізувалося як взаємодія педагогів та учнів із метою виконання навчальних програм засобами інтернет-технологій. Пандемія COVID-19 змусила українських педагогів добирати прості інструменти для підтримки освітнього прочесу. Незважаючи на наявність значної кількості изифрових інструментів для організачї дистаниійної форми, навчання учнів не сприяло швидкому та ефективному переходу 33 СО до неперервного навчання під час пандеміі, зокрема для виконання навчальних програм $і$ задоволення освітніх потреб учням, які активно використовують мобільні телефони, планшети, ноутбуки тощзо, часто не вистачало компетентного в цифрових технологіях та ичиррового освітнього контенту вчителя.

Проаналізовано міжнародні статистичні дані стосовно діяльності закладів освіти у період карантину, стан використання інтернет-ресурсів вітчизняними педагогами, діяльність керівників 33СО iз метою забезпечення неперервності в навчанні. Обгрунтовано такі моделі дистанційного навчання, як «Урок-вебінар» $i$ «Віртуальний клас», окреслено систему сервісів для їх реалізації, зокрема проведення лабораторних і практичних робіт, узагальнення, комунікації та обговорення. Запропоновано чотири кроки до впровадження дистанційного навчання у систему вітчизняних 3ЗСО. Установлено, щзо поліпшення освітнього процесу здійснюється за такими напрямами: розвиток освітнього середовища, використання інноваційних засобів навчання, впровадження новітніх технологій навчання, удосконалення організаційних форм навчання.

Ключові слова: дистаниійне навчання, моделі дистаниійного навчання, інтернет-сервіси, заклади загальної середньої освіти, COVID-19.

В статье охарактеризован вопрос дистанционного обучения учашихся учреждений общего среднего образования (УОСО) в период пандемии. Доказано, что, несмотря на рекомендации ЮНЕСКО, дистаничионное обучение в отечественных учреждениях общего среднего образования реализовалось как взаимодействие педагогов и учащихся с иелью выполнения учебных программ средствами интернет-технологий. Пандемия COVID-19 заставила украинских педагогов подбирать простые инструменты для поддержки образовательного прочесса. Несмотря на наличие значительного количества ицифровых инструментов для организачии дистанционной формы, обучение учашихся не способствовало быстрому и эффективному переходу УОСО к непрерывному обучению во время пандемии: для выполнения учебных программ и удовлетворения образовательных потребностей ученикам, которые активно используют мобильные телефоны, планшеть, ноутбуки и др., часто не хватило компетентного в циифровых технологиях и цчифрового образовательного контента учителя.

Проанализированы международные статистические данные о деятельности учебных заведений 8 период карантина, состояние использования интернет-ресурсов отечественными педагогами, деятельность руководителей 33 СО с иелью обеспечения непрерывности в обучении. Обосновань такие модели дистанционного обучения, как «Урок-вебинар» $и$ «Виртуальный класс», обозначена система сервисов для их реализации, включая проведение лабораторнblх и практических работ, обобщения, коммуникации и обсуждения. Предложень четыре шага $к$ внедрению дистанционного обучения в систему отечественных УОСО. Установлено, что улучшение образовательного проиесса осуществляется по следующим направлениям: развитие образовательной среды, использование инновачионных средств обучения, внедрение новейших технологий обучения, совершенствование организационных форм обучения.

Ключевые слова: дистанционное обучение, модели дистанционного обучения, интернет-сервисы, учреждения общего среднего образования, COVID-19.

The issue of distance learning of general secondary education institutions (GSEI) students provided during the pandemic is considered in the article. Despite the recommendations of UNESCO, distance learning in domestic general secondary education institutions was implemented as a teacher-student interaction done by means of the Internet technology in order to fulfill the curricula. 
The COVID-19 pandemic has forced domestic educators to choose simple tools to support the educational process. The existence of a significant number of digital tools for the students distance learning organization did not contribute to the rapid and effective transition of GSEI to the uninterrupted learning during the pandemic. A lack of teacher competence in digital technologies as well as lack of digital educational content was seen which prevented the teachers both from providing the smooth curricula implementation and meeting the educational needs of students who actively use mobile phones, home tablets, laptops, etc.

International statistical data on the activities of educational institutions during quarantine, as well as the state of Internet resources use by domestic teachers were analyzed, the activities of the heads of GSEI to ensure continuity of learning, two models of distance learning "Webinar» and «Virtual Classroom» were substantiated, the system of services for two models of distance learning implementation was described, both for laboratory and practical work, as well as for generalization, communi- cation and discussion; four steps to the distance learning introduction in the system of GSEI were proposed.

The article establishes the idea that the improvement of the educational process is carried out in the following areas: educational environment development, innovative teaching aids use, new learning technologies introduction, and organizational learning forms improvement.

Key words: distance learning, distance learning models, Internet services institutions of general secondary education, COVID-19.

Постановка проблеми. Пандемія COVID-19, як відомо, внесла корективи у діяльність усіх освітніх установ світу (див. рис. 1) (https://en.unesco.org/ covid19/educationresponse), зокрема вона спричинила повсюдне закриття початкових і середніх шкіл у 150ти країнах світу та масове переведення учнів (понад 1,18 млрд осіб, тобто 68,9\%) на дистанційну форму навчання [12]. Як наслідок-у зв'язку із поширенням COVID-19 кожен п'ятий учень у світі не відвідував школу [16].
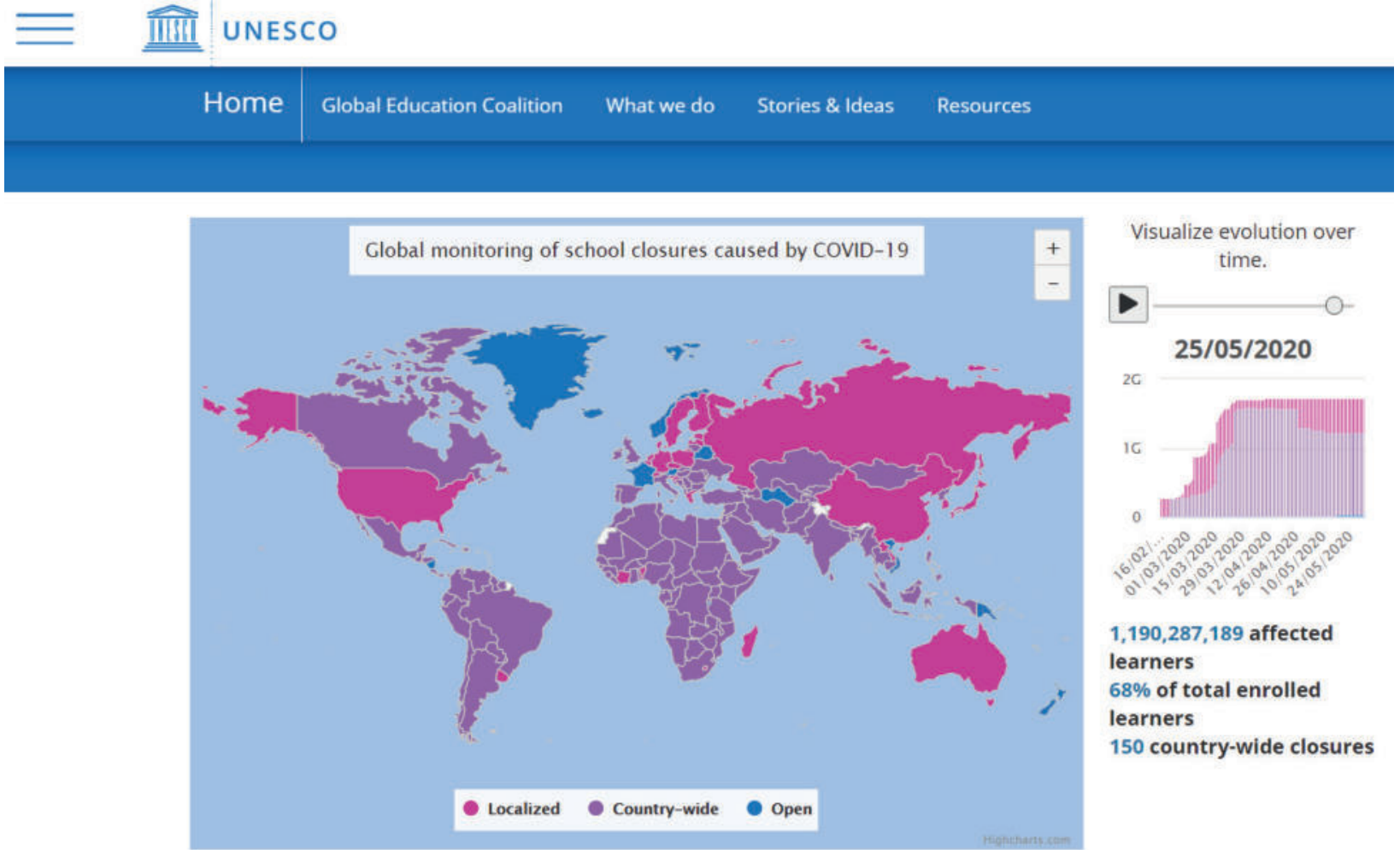

Visualize evolution over time.
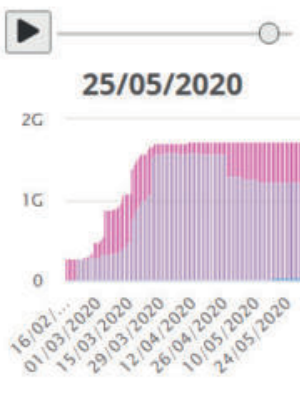

$1,190,287,189$ affected learners

$68 \%$ of total enrolled learners

150 country-wide closures

Рис. 1. Глобальний моніторинг закриття шкіл

Для швидкого реагування на ситуацію Організацією ЮНЕСКО було розроблено рекомендації щодо організації онлайн-навчання учнів:

- перевірити готовність і відібрати відповідні інструменти для здійснення дистанційної форми навчання, визначитися з доступом до мережі Інтернет, рівнем цифрових навичок вчителів і учнів;

- здійснювати навчання учнів як на інтегрованих цифрових навчальних платформах, так і з використанням відеоуроків, МООС, радіо і телебачення;

- забезпечити доступ учнів до дистанційного навчання та вжити заходів для забезпечення учнів 3 особливими потребами доступом до навчальних матеріалів;

- забезпечити захист конфіденційних даних, оцінити безпеку завантаження освітніх ресурсів із веб- простору, переконатися, що використання додатків і платформ не порушує конфіденційності учнів;

- визначити пріоритетні заходи для розв'язання психосоціальних проблем перед навчанням (зокрема використання доступних інструментів для зв'язку між батьками, учителями й учнями);

- розробити чіткий графік дистанційного навчання, уточнити, програма дистанційного навчання буде зосереджена на навчанні нових знань чи сприятиме розширенню знань учнів із попередніх тем;

- надати підтримку вчителям і батькам у питанні використання цифрових інструментів, організувати короткі тренінги або ознайомчі заняття для вчителів і батьків;

- обмежити кількість додатків і платформ, здійснити добір інструментів, які доступні для більшості учнів як для синхронного, так і асинхронного навчання; 
- розробити опитувальники, тести, контрольні завдання 3 метою здійснення моніторингу процесу навчання учнів;

- визначити тривалість уроку під час дистанційного навчання, грунтуючись на навичках учнів: дотримуватися тимчасових рамок, відповідно до рівня метакогнітивних здібностей учнів, особливо на уроках прямої трансляції;

- дотримуватися тривалості дистанційного уроку: для учнів початкової школи не більше 20 хвилин, для учнів середньої школи - не більше 40 хвилин;

- створити спільноти вчителів, батьків і керівників шкіл для обміну досвідом та обговорення стратегій подолання труднощів, що виникатимуть у процесі навчання [4].

Незважаючи на представлені вище рекомендації, дистанційне навчання у вітчизняних закладах загальної середньої освіти відбувалося у формі взаємодії педагогів та учнів із метою виконання навчальних програм засобами інтернет-технологій. Крім того, пандемія COVID-19 змусила українських педагогів змінити ставлення до технологій дистанційного навчання, як-от добирати для підтримки освітнього процесу прості інструменти. Однак наявність значної кількості інструментів для організації дистанційної форми навчання учнів не сприяла під час пандемії швидкому й ефективному переходу закладів загальної середньої освіти до неперервного навчання: для виконання навчальних програм і задоволення освітніх потреб учням, які активно використовують мобільні телефони, планшети, ноутбуки тощо, часто не вистачило вчителя, компетентного у цифрових технологіях.

Сучасним учителям досить важко навчати учнів засобами інтернет-технологій, адже вони не тільки не мають достатнього досвіду та навичок цифрового освітнього контенту, а багатьом із них не вистачає методичної підтримки, дидактичних матеріалів, комплексних рішень для здійснення дистанційного навчання. Крім того, значна частина вчителів, зокрема фізики, хімії та біології, не змогли використати готові системи комп'ютерного моделювання (СКМод), оскільки не мали досвіду онлайнової співпраці з учнями.

Аналіз наукових досліджень і публікацій. Ще у 2004 році Т. Андерсон (Т. Anderson) визначив основні онлайн-інструменти для використання у ході дистанційного навчанні (див. рис. 2). Зокрема, він порівняв їхню здатність підтримувати незалежність (від часу і місця) зі здатністю до взаємодії. 3'ясувалося, що чим вища форма спілкування, тим більше обмежень вона накладає на незалежність [13, с. 44].

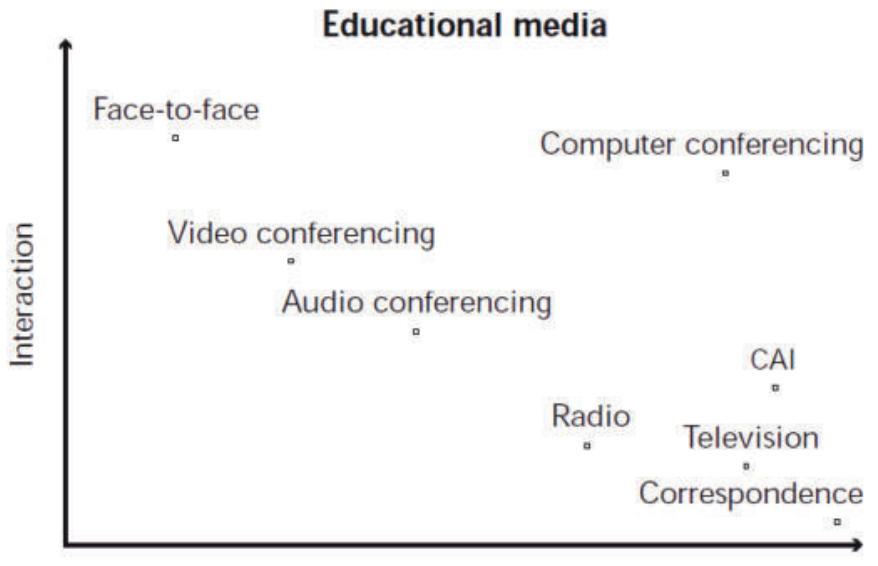

Independence of time and distance

Рис. 2. Інструменти дистанизійного навчання (за Т. Андерсоном)

До ключових засобів учений відніс відеоконференції, аудіоконференції, кореспондентську форму комунікації і комп’ютерні конференції (вебінари), що надзвичайно популярні й сьогодні.

Із розвитком технологій значне місце в дистанційному навчанні зайняли LMS (системи управління навчанням) та МООС (масові відкриті онлайнові курси), про що у своїх роботах зазначають як вітчизняні вчені (В. Кухаренко [6], Н. Морзе, В. Биков [2], I. Адамова та Т. Головачук [1], В. Ясулайтіс), так і зарубіжні (С. Полат, М. Бухаркіна, В. Моісеєва та ін.). Проте у 33 СО ці системи не набули поширення, адже освітній процес у них значно відрізнявся від навчання у закладах вищої освіти.

В. Кухаренко, наголошуючи на проблемах упровадження дистанційної форми навчанні, зауважував, що до них передусім слід віднести: слабку підтримку дистанційного навчання керівниками закладів освіти, низьку мотивацію педагогічних працівників та їхню інформаційну грамотність, а також акцентував увагу на тому, що рівень інформаційної грамотності педагогічного працівника можна оцінити завдяки його персональному навчальному середовищу, тобто інструментам, які він використовує у своїй професійній діяльності [5, с. 37].

До початку пандемії COVID-19 рівень інформаційної грамотності вчителів-предметників дозволяв їм достатньою мірою здійснювати свої професійні обов'язки, однак у ситуації, що склалася в умовах пандемії, з'ясувалося, що цього рівня недостатньо для здійснення дистанційного навчання i підтримання цифрової комунікації з учнями та батьками.

Мета статті - проаналізувати та обгрунтувати основні засоби й інтернет-сервіси для організації дистанційного навчання учнів закладів загальної середньої освіти у період довготривалого карантину, визначити основні кроки для впровадження такої форми навчання в освітній процес.

Виклад основного матеріалу. Упровадження дистанційного навчання у систему вітчизняних закладів загальної середньої освіти, зокрема й в умовах епідемії, - справа не з легких. Тож, переконані, наші поради - на часі. 
1. Аналіз стану використання дистанційної форми навчання в закладах загальної середньої освіти України. Протягом березня-квітня 2020 року групою науковців Інституту інформаційних технологій і засобів навчання НАПН України було опитано 607 учителів закладів загальної середньої освіти (далі - 33СО) щодо організації дистанційної форми навчання під час пандемії COVID-19. Аналізуючи отримані дані, було встановлено:

- для миттєвих повідомлень і оголошень учителі використовували: Viber - 88,2\%, Telegram - 20,9\%, сайт закладу освіти - 62,7\%;

- для організації роботи з класом вони скористалися Google Classroom - 45,5\%, Microsoft Teams $4,7 \%$, Moodle $-3,4 \%$;

- додаткові матеріали до уроків вони добирали на каналі YouTube - 72,9\%, платформах EdEra - 42,3\%, Prometheus - 32,5\%;

- для учнів старших класів вони включили онлайн-курси МОН України з підготовки до ЗНО $27,3 \%$, відеоуроки на ТРК «Київ» - 22,8\%, платформу «Цифрова освіта «Дія»»» - 15,4\%, відеоуроки на місцевих телеканалах $-11,8 \%$.

- для організації уроків-вебінарів використовували: Skype - 37,7\%, Zoom - 28,5\%.

- електронний щоденник використали - 10,3\%.

Крім того, вчителі перебували в прямому ефірі 3-4 години на день, стільки ж їм знадобилося часу для підготовки до уроків. У вихідні дні вони виділяли 2-3 години на опанування простих сервісів 3 метою підтримування онлайн-зв'язку з учнями.

У процесі стрімкої перебудови освітнього процесу спостерігалися такі основні перешкоди у впровадженні дистанційної форми навчання:

- недостатні технічні можливості - 61\%;

- недостатній досвід учителів - 58,6\%;

- обмежений доступ до мережі Інтернет - 35,3\%;

- недостатність інформації для здійснення навчання $-20,2 \%$;

- відсутність чітких інструкцій від адміністрації $33 \mathrm{CO}-10 \%$;

- недостатня мотивованість учителів - 7,8\%.

Отже, готовність учителів до здійснення означеного виду діяльності зазвичай була низькою. Учителям доводилося докладати значних зусиль (технічних, психологічних та ін.) для налагодження такого виду роботи з учнями.

2. Управлінський аспект упровадження дистанційної форми навчання. МОН України підготувало наказ від 16.03.2020 № 406 «Про організаційні заходи для запобігання поширенню коронавірусу COVID-19» [11], де зазначається, що на період карантину потрібно забезпечити виконання освітніх програм закладів освіти, зокрема шляхом організації освітнього процесу із використанням технологій дистанційного навчання.

Перед адміністрацію закладів освіти постало непросте завдання - організувати альтернативний до очного навчання освітній процес [8], що потребувало негайного виконання таких видів робіт:

- формування банку електронних скриньок учителів та учнів;

- формування банку мобільних номерів, який би відповідав усім вимогам щодо захисту персональних даних;

- добір системи засобів для здійснення дистанційного навчання;
- перевірка наявного комп’ютерного обладнання вчителів; учнів;

- перевірка наявного комп'ютерного обладнання

- створення розкладу-графіка онлайн-уроків;

- фіксація проведених уроків;

- добір форм контролю виконання домашніх завдань учнями;

- добір інструментів для оцінювання навчальних досягнень учнів;

- пошук якісного цифрового освітнього контенту;

- термінове навчання вчителів щодо використання цифрових засобів для здійснення дистанційного навчання [14].

Усі означені вище заходи потребували часу, кожна школа мала визначитися із власною моделлю здійснення освітнього процесу, а кожен учитель відповідно - обрати для себе зручні інструменти, забезпечивши таким чином виконання освітньої програми.

Для учнів і батьків це стало своєрідною проблемою: кожен учитель використовував у роботі різні інструменти, не задумуючись при цьому про те, яким чином учні мають їх опанувати. Тобто, скільки вчителів - стільки й варіантів організації дистанційного навчання, а це, як відомо, викликало неабияке незадоволення в батьків.

Перед адміністрацією закладів освіти постала проблема добору моделі організації дистанційної форми навчання на рівні навчального закладу й підготовки всіх вчителів до виконання такої освітньої діяльності.

3. Особливості організації дистанційної форми навчання в $33 \mathrm{CO}$ у період пандемії. Порівнюючи вітчизняний досвід із зарубіжним, зауважимо, що дистанційна форма навчання може реалізовуватися як із використанням мережі Інтернет (онлайн), так і без неї (офлайн) [3; 8; 10]. Відрізняються вони лише тим, що в першому випадку освітній контент знаходиться на сайтах, порталах чи в системах дистанційного навчання, а в другому - завантажується на комп'ютер учня і використовується без доступу до мережі Інтернет. Крім того, онлайн-навчання може здійснюватися як синхронно (передбачає обов'язкову одночасну присутність учителя й учнів), так і асинхронно (коли учень може навчатися у зручний для нього час без обов'язкової присутності вчителя, наприклад, перегляд відео уроків).

Пропонуємо дві моделі організації дистанційної форми навчання учнів, які найчастіше обирали вчителі під час пандемії, - «Урок-вебінар» та «Віртуальний клас» (див. рис. 3).

Модель «Урок-вебінар». Учителі й учні мали обмежений доступ до комп'ютерів, але при цьому мали доступ до мережі Інтернет, зокрема через мобільні телефони.

Для організації онлайн-навчання учнів педагоги дотримувалися такої послідовності:

- створення графіка уроків-вебінарів, який відповідає розкладу занять закладу освіти;

- проведення «прямого ефіру» з учнями, під час якого педагоги коментують та пояснюють навчальний матеріал, відповідають на запитання учнів, коментують виконання домашніх завдань, окреслюють терміни надсилання виконаних завдань;

- учні виконують домашні завдання у зручний для них час, дотримуючись режиму дня;

- виконані завдання учні надсилають учителям безпосередньо на електронну пошту або розміщують у хмарному сховищі - Google Drive, One Drive 


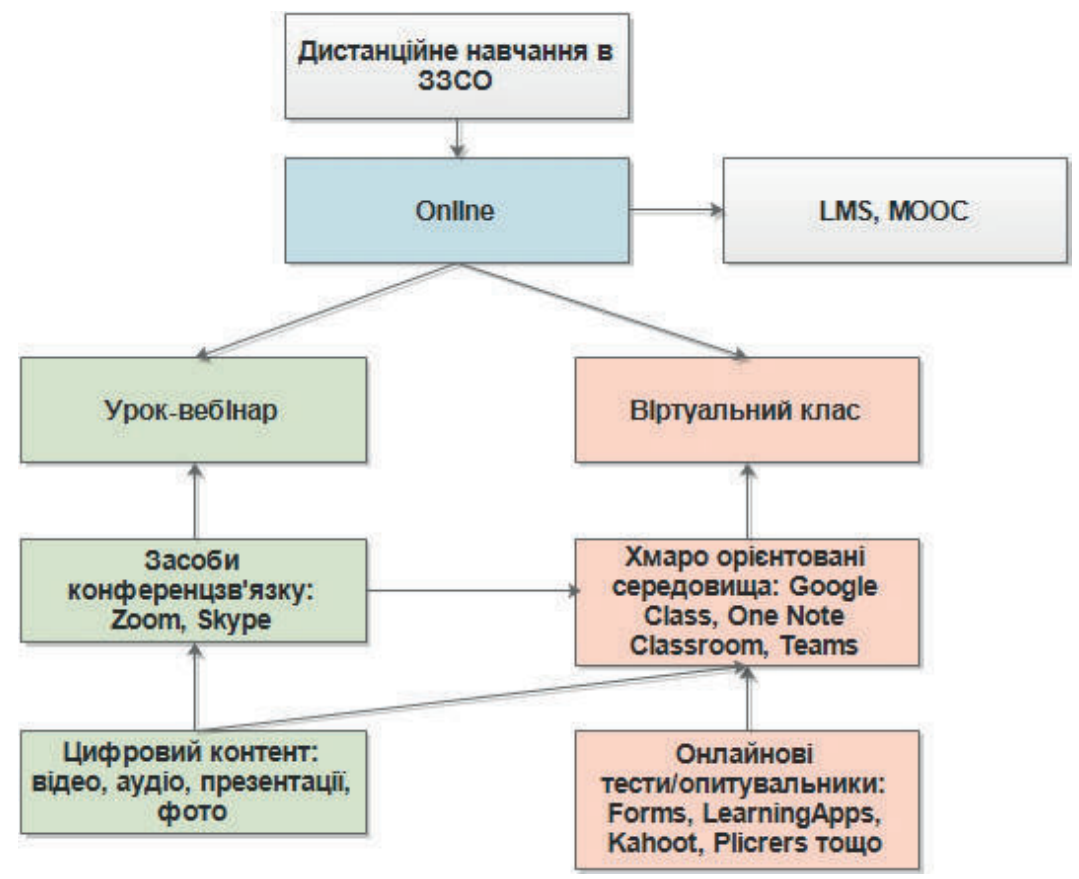

Рис. 3. Моделі організації дистанційного навчання в З3СО

(це можуть бути як фото виконаних завдань, так i скріни екрана чи скановані копіі).

- учителі оцінюють роботи учнів і повідомляють їм результати електронною поштою (наприклад, узагальнено за період) або фіксують оцінки в електронних журналах.

Представлене вище навчання здійснюється за безпосередньої участі вчителя, тобто за його присутності під час «прямого ефіру». У разі виявлення певних проблем, учень може надіслати вчителеві коротке повідомлення.

Модель «Віртуальний клас». Для організації онлайн-навчання учнів із використанням системи інтернет-сервісів, зокрема й хмаро орієнтованих, учителі дотримуються такої послідовності:

- учителі створюють віртуальні класи завдяки засобам хмаро орієнтованих технологій для конкретного класу або паралелі класів [8]. Учні отримують посилання або код для входу у віртуальний клас (Teams, OneNote Classroom, Google Class);

- учителі розміщують у віртуальному класі цифровий освітній контент для повсюдного доступу до нього учнів;

- створення графіка уроків-вебінарів, показ відео або змістовних відеопрезентацій, що відповідають розкладу занять закладу освіти;

- учителі проводять «прямий ефір» 3 учнями згідно з розкладом, коментують та пояснюють навчальний матеріал, відповідають на запитання учнів, коментують виконання домашніх завдань, встановлюють терміни надсилання виконаних завдань (інший варіант - не виходячи у «прямий ефір», моніторять тільки виконання домашніх завдань);

- учні виконують завдання у зручний для них час;

- учні розміщуються виконані завдання у хмарному сховищі - Google Drive, One Drive (це можуть бути як фото виконаних завдань, так і скріни екрана чи скановані копії;

- учителі проводять опитування й тестування 3 теми уроку;
- учителі оцінюють роботи учнів та виставляють оцінки в електронний журнал.

Таке навчання здійснюється як за участю вчителя, так і без нього. У разі виникнення освітніх проблем учень може надіслати вчителеві коротке повідомлення.

4. Системи та сервіси для організації дистанційної форми навчання. Кількість інтернет-сервісів для організації дистанційної форми навчання сягає на сьогодні сотні найменувань, але серед учителів найбільшою популярністю користуються Google Class, Teams, OneNote Classroom. Вибір обумовлений простотою організації дистанційної форми навчання, безкоштовним доступом до основних функцій, рівнем цифрової підготовки вчителів здійсненим передусім в інститутах післядипломної педагогічної освіти.

Google Class - сервіс, доступ до якого відбувається з електронної скриньки Google-аккаунта. За допомогою сервісу вчитель має можливість створювати поурочну структуру, розміщувати теоретичний матеріал, аудіо- та відеофайли, посилання на тести тощо. Виконані завдання учні підвантажують до завдання і вчитель може перевірити їх у зручний для нього час. Серед переваг даного сервісу - автоматичне формування електронного журналу та бальне оцінювання завдань. До особливостей використання сервісу варто віднести вікове обмеження (особи від 12 років) на створення Google-аккаунта, однак ця проблема легко вирішується за умови створення електронної скриньки батьками учня.

OneNote Classroom (складова Office 365) - cepвіс, завдяки якому реалізується повноцінний віртуальний клас, що включає три освітні кабінети:

- бібліотека навчальних матеріалів - тільки читання та перегляд матеріалів;

- кабінет для співпраці - освітня зона для спільної роботи, проєктної діяльності, обговорення, коментування;

- кабінет учня - для розміщення виконаних завдань або електронних робочих зошитів. 
Серед переваг даного сервісу - необмежений доступ до навчальних матеріалів, захист персональних даних, адміністративна підтримка учня, створення корпоративної пошти навчального закладу. До особливостей використання сервісу слід віднести обов'язкову наявність облікового запису Microsoft або Office 365.

Teams - комплексне рішення як для вчителя зокрема, так і всього закладу освіти загалом. У цьому інтернет-сервісі поєдналися OneNote Classroom, системи конференцзв'язку та миттєвих повідомлень, що надає переваги для його використання в системі освіти. До переваг сервісу варто віднести можливість формування груп, а до його особливостей - обов'язкову наявність облікового запису Microsoft або Office 365.

Сервіси для проведення уроків-вебінарів у період пандемії COVID-19 набули широкого розповсюдження серед учителів закладів загальної середньої освіти. Це було обумовлено тим, що учні мали потребу у роз'ясненні науково-теоретичних положень, викладених у навчальному матеріалі та демонстрації способів і методів розв'язання завдань. Серед низки сервісів вчителі надали перевагу передусім Zoom i Skype.

Zoom - простий і доступний у використанні сервіс для будь-якого ступеня ІК-підготовки педагогічних працівників, його легко опанували навіть учні початкової школи.

Skype - більш потужний та поширений сервіс, що підтримується компанією Microsoft.

Обидва сервіси мають достатній функціонал для проведення уроків-вебінарів. Основною проблемою залишається «видимість учня під час уроку», зокрема кількість онлайнових зображень учасників уроку досі залишається малою.

Google Meet - найновіший сервіс, що з'явився в останні тижні карантину, а отже, і досі знаходиться на етапі широкомасштабного апробування, доопрацювання і розвитку. Він має неабиякий потенціал стосовно використання в системі освіти, оскільки є складовою електронної скриньки, тобто завжди «під рукою».

У період карантину педагогічні працівники також мали можливість безкоштовно скористатися сервісом Webex від компанії Cisco, однак у роботі даний сервіс виявився досить складним, наприклад, спостерігалися проблеми 3 передачею потокового відео і зображень, учасники відзначали проблеми із входом, під час заходу виникала необхідність перезавантаження і повторного входу.

Сервіси для організації лабораторних і практичних робіт, системи комп'ютерного моделювання. Технологічні зміни в IT-сфері призвели до оновлення онлайнових наочних засобів із природничих предметів для організації та проведення лабораторних і практичних робіт. Зокрема, позитивно зарекомендували себе нові системи комп'ютерного моделювання [9] процесів і об'єктів, як-от: Phet (https://phet.colorado. edu); CK-12 (https://www.ck12.org); Mozaik (www. mozaweb.com); GeoGebra (https://www.geogebra.org). Робота в таких системах передбачає використання 2Dта 3D-моделей реальних об'єктів світу, що надає можливості вчителеві створити цікавий інноваційний урок або спроєктувати дослідницьку роботу (див. рис. 4).
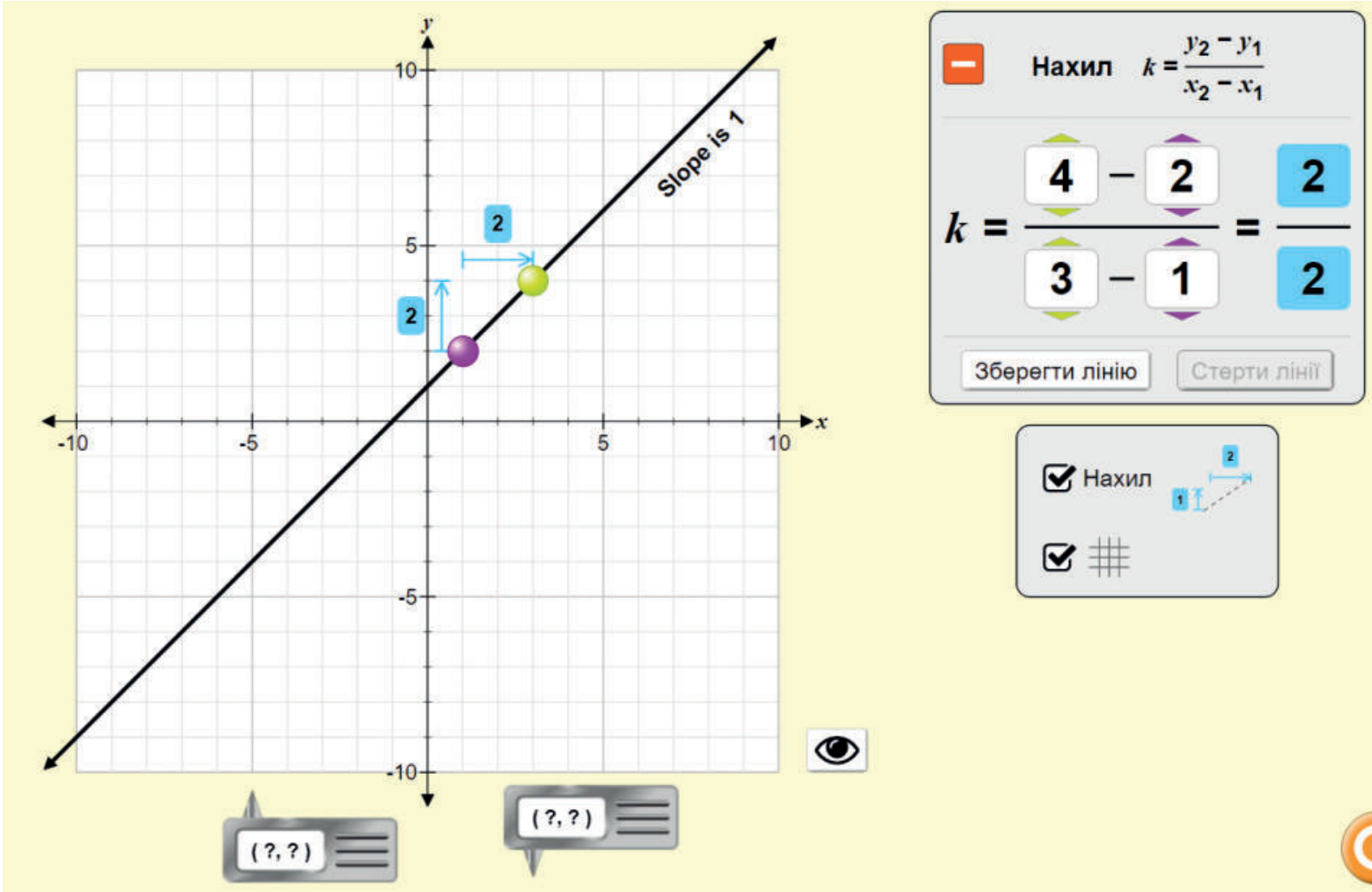

Рис. 4. Комп 'ютерна модель «Кутовий коефіиієнт»»

Форма організаційної онлайнової практичної роботи для учнів - фронтальна. Учитель, використовуючи комп'ютерні моделі, демонструє різні процеси й об'єкти, а учні при цьому виконують завдання $і н д и в і-$ дуально - відповідно до власної траєкторії розвитку, особистих здібностей та змісту отриманих домашніх завдань.

Форми організації онлайнової лабораторної роботи - індивідуальна. Кожен учень отримує індивідуальне завдання, яке має виконати незалежно від інших 
iз використанням комп'ютерних моделей; діяльність учителя під час проведення таких лабораторних занять полягає в оцінюванні результатів, креативності та творчих підходах учнів. Обговорення результатів лабораторної роботи може відбуватися засобами конференцзв'язку.

До інновацій варто віднести використання об 'єктів доповненої реальності (AR). Сучасні мобільні пристрої та додатки дозволяють використовувати такі об'єкти у ролі інструменту візуалізації освітнього контенту. Нині розрізняють такі типи контенту доповненої реальності, що модернізують звичайний контент: візуальні (2D-об'єкти, 3D-об'єкти); аудіальні (об'єкти, що мають аудіосупровід (озвучення): поезія, пісня, прислів'я, текст); контролювальні (інтерактивні тести трьох типів: читати - надати відповідь, слухати - надати відповідь, вибір правильної відповіді із запропонованих). Такі об'єкти легко інтегруються в дистанційне навчання.

Сервіси для узагальнення, обговорення, комунікації. Найбільш популярними сервісами для організації співпраці вчителі назвали: Padlet (https:// uk.padlet.com/) та Linoit (https://en.linoit.com/). Привабливим для створення відеозаписів виявився Flipgrid (https://info.flipgrid.com/), зокрема завдяки йому вчителі іноземної мови, української та зарубіжної літератури змогли зібрати відеозвіти, де представлено декламування віршів, перекази текстів тощо.

Сервіси для створення онлайн-тестів, опитувальників також набули неабиякої популярності в освітньому процесі.Середних-Mentimeter(https://www.mentimeter. com); Kahoot (https://kahoot.com); ClassMarker (https:// www.classmarker.com); Plickers (https://get.plickers.com); EasyTestMaker (https://www.easytestmaker.com); Quizlet (https://quizlet.com). За допомогою цих сервісів учителі мали змогу створювати вікторини, тести, в яких учні мали змогу обрати правильну відповідь із кількох запропонованих, зіставити зображення та інформацію або вписати власні варіанти відповідей.

Висновки. Зважаючи на представлений у нашому дослідженні матеріал, можемо зазначити, що перший масовий досвід використання дистанційної форми навчання в закладах загальної середньої освіти мав не лише позитивні моменти, а й чимало недоліків і нарікань. Однак учителі зробили все можливе, щоб навчання було неперервним.

У зв'язку з цим пропонуємо чотири основні кроки до впровадження дистанційної форми навчання для забезпечення неперервності в освіті:

- цільове підвищення компетентності педагогічних працівників із базових сервісів для організації дистанційної форми навчання;

- цільове формування цифрового освітнього простору закладів освіти - Інтернет, комп'ютерне обладнання, засоби комунікації, програмне забезпечення, зокрема й електронні щоденники / журнали;

- розроблення науково-методичних матеріалів із питань дистанційного навчання (для керівників, учителів, учнів, батьків);

- розробка якісного освітнього контенту із предметів шкільного курсу за умов співпраці з Мінфіном щодо визначення вартості.

\section{СПИСОК ВИКОРИСТАНОЇ ЛІТЕРАТУРИ}

1. Адамова I. 3., Головачук Т. I. Дистанційне навчання: сучасний погляд на переваги та проблеми. $B u$ токи педагогічної майстерності. 2012. Вип. 10. С. 3-6. (Серія «Педагогічні науки»).
2. Биков В. Ю. Дистанційна освіта: актуальність, особливості та принципи побудови, шляхи розвитку та сфера застосування. Інформаційне забезпечення навчально-виховного процесу: інновачійні засоби i технології : колективна монографія. Київ : Атіка, 2005. С. 77-92.

3. Буров О. Ю. Технології й інновації в діяльності людини ери інформації: інформація і технології. Інформаційні технології $i$ засоби навчання. 2015. № 5 (49). С. 16-26.

4. Как планировать решения для дистанционного обучения во время закрытия временных школ / ЮHЕCKO. URL: https://en.unesco.org/news/covid-1910-recommendations-plan-distance-learning-solutions (дата звернення: 31.05.2020).

5. Кухаренко В. М. Перешкоди впровадженню дистанційного навчання. URL: https://cutt.ly/yyNfnqr (дата звернення: 31.05.2020).

6. Кухаренко В. М. Про систему дистанційного навчання у відкритому дистанційному курсі. Інформаційні технологї в освіті. 2012. Вип. 11. С. 32-42.

7. Литвинова С. Г. Інформаційно-комунікаційні компетентності вчителів загальноосвітніх навчальних закладів. Комп'ютер у школі та сім'ї. 2011. № 5 (93). С. 6-10.

8. Литвинова С. Г. Методика проектування хмаро орієнтованого навчального середовища загальноосвітнього навчального закладу на рівні керівника. Комп ’ютер у школі та сім’ї. 2015. № 2 (122). С. 5-11.

9. Литвинова С. Г. Модель використання системи комп'ютерного моделювання для формування компетентностей учнів із природничо-математичних предметів. Фізико-математична освіта. Суми : [СумДПУ ім. А. С. Макаренка], 2019. Т. 1 (19). С. 108-115. URL: https://doi.org/10.31110/2413-1571-2019-019-1017 (дата звернення: 31.05.2020).

10. Теорія і практика змішаного навчання : монографія / В. М. Кухаренко та ін. ; [за ред. В. М. Кухаренка]. Харків : Міськдрук ; НТУ «ХПІ», 2016. 284 с.

11. Щодо організації дистанційного навчання в закладах загальної середньої освіти під час карантину. URL: https://cutt.ly/dyB9CuF (дата звернення: 31.05.2020).

12. COVID-19 Educational Disruption and Response. URL: https://en.unesco.org/covid19/educationresponse (дата звернення: 31.05.2020).

13. Anderson T. Towards a theory of online learning. Theory and practice of online learning, 2004. Vol. 2. P.109-119.

14. Lytvynova S., Melnyk O. Professional Development of Teachers Using Cloud Services During Non-formal Education. Proc. of 1st Workshop 3L-Person'2016/ Kyiv, 2016/ June 21-24. P. 648-655. URL: http://ceur-ws.org/Vol-1614/paper_51.pdf (дата звернення: 31.05.2020).

15. Pinchuk O., Burov O., Lytvynova S. (2020) Learning as a Systemic. Advances in Human Factors in Training, Education, and Learning Sciences. AHFE 2019. Advances in Intelligent Systems and Computing, Vol. 963. P. 335-342. URL: https://doi.org/10.1007/9783-030-20135-7_33 (дата звернення: 31.05.2020).

16. With one in five learners kept out of school, UNESCO mobilizes education ministers to face the COVID-19 crisis. URL: https://cutt.ly/JyNgqJR (дата звернення: 31.05 .2020$)$.

Дата надходження до редакиії: 08.06.2020 p. 